\title{
Pengaruh Konseling Apoteker Terhadap Hasil Terapi Pasien Hipertensi di Poliklinik Penyakit Dalam RSUD Kraton Kabupaten Pekalongan
}

\author{
Anita Budi Mulyasih", Djoko Wahyono², I Dewa Putu Pramantara ${ }^{3}$ \\ ${ }^{1}$ Balai POM Kupang \\ ${ }^{2}$ Fakultas Farmasi, Universitas Gadjah Mada \\ ${ }^{3}$ Rumah Sakit Dr. Sardjito Yogyakarta
}

\begin{abstract}
Prevalence of Hypertension increased in line with changes of life style as smoking, obesity, non physical activity, psycho-social stress in many countries. Comprehensive and intensive treatment could be more control of blood pressure. Understood, knowledge and adherence of patient expected will improve along with act of distributed useful and correct information by pharmacist. The aim this study to determine the effect of counseling pharmacist on therapeutic outcomes and adherence and to know the correlation between therapeutic outcomes and adherence of outpatients hypertensive in the internal disease clinic at RSUD Kraton Pekalongan District. This research was experimental intervention with pre-post intervention with randomized without matching. Data was collected by prospective method. The control group given a leaflet at the first month, and the intervention group given a leaflet at the first month and counseling every early month, during 3 months. There was 75 patients, the intervention group $(\mathrm{N}=39)$ experienced a significant decrease in blood pressure at the end of the study, on systolic amounted 11.28 \pm 8.33 $\mathrm{mmHg}[\mathrm{P}=0.000(\mathrm{P}<0.05)]$ and diastolic amounted 7.18 $\pm 6.86 \mathrm{mmHg}[\mathrm{P}=0.000(\mathrm{P}<0.05)]$, whereas in the control group $(\mathrm{N}=36)$ did not experience a significant decrease in blood pressure is systolic amounted $2.22 \pm 10.45 \mathrm{mmHg}[\mathrm{P}=0.203(\mathrm{P}>0.05)]$ and diastolic amounted $0.28 \pm 6.09$ $\mathrm{mmHg}[\mathrm{P}=0.782(\mathrm{P}>0.05)]$. Adherence of patients as measured by MMAS scale in the intervention group better adherence than the control group $(33.33 \%: 2.78 \%)$. There was have correlation a means between MMAS score with change of systolic $(\mathrm{P}=0.019 ; \mathrm{r}=0.270)$ and diastolic $(\mathrm{P}=0.001$; $\mathrm{r}=0.372$ ) which positive direction. It was concluded that counseling has an effect on adherence positively in the intervention group better than the control group and decreasing systolic and diastolic blood pressure until reach targets. There was a close correlation between decrease in blood pressure with MMAS score in hypertensive patients.
\end{abstract}

Key Words : Hypertension, counseling, outpatient, adherence

\begin{abstract}
ABSTRAK
Prevalensi hipertensi meningkat sejalan dengan perubahan gaya hidup seperti merokok, obesitas, inaktivitas fisik, dan stres psikososial di banyak negara. Penanganan yang komprehensif dan intensif diharapkan dapat mengontrol tekanan darah. Pemahaman, pengetahuan dan kepatuhan pasien diharapkan akan meningkat seiring dengan pemberian informasi yang tepat dan bermanfaat oleh Apoteker. Tujuan penelitian ini untuk mengetahui pengaruh konseling Apoteker terhadap hasil terapi dan kepatuhan serta untuk mengetahui hubungan antara hasil
\end{abstract}


terapi dan kepatuhan pasien hipertensi rawat jalan di poliklinik penyakit dalam RSUD Kraton Kabupaten Pekalongan.

Penelitian ini merupakan penelitian intervensional eksperimental dengan pra-pascaintervensi dengan randomisasi tanpa penyetaraan. Pengambilan data dilakukan secara prospektif. Kelompok kontrol diberikan leaflet pada bulan pertama, pada kelompok perlakuan diberikan leaflet pada bulan pertama dan konseling tiap awal bulan selama 3 bulan.

Dari 75 pasien, kelompok perlakuan $(\mathrm{N}=39)$ mengalami penurunan tekanan darah yang bermakna pada akhir penelitian yaitu sistolik sebesar $11.28 \pm 8.33 \mathrm{mmHg}[\mathrm{P}=0.000(\mathrm{P}<0.05)]$ dan diastolik sebesar 7.18 $\pm 6.86 \mathrm{mmHg}[\mathrm{P}=0.000(\mathrm{P}<0.05)]$, sedangkan pada kelompok kontrol $(\mathrm{N}=36)$ tidak mengalami penurunan tekanan darah yang bermakna yaitu sistolik sebesar $2.22 \pm 10.45 \mathrm{mmHg}$ $[\mathrm{P}=0.203(\mathrm{P}>0.05)]$ dan diastolik sebesar $0.28 \pm 6.09 \mathrm{mmHg}[\mathrm{P}=0.782(\mathrm{P}>0.05)]$. Kepatuhan pasien yang diukur dengan skala MMAS pada kelompok perlakuan menunjukkan kepatuhan yang lebih baik dibandingkan dengan kelompok kontrol (33.33\% : 2.78\%). Terdapat korelasi yang bermakna antara skor MMAS dengan perubahan sistolik ( $\mathrm{P}=0.019 ; \mathrm{r}=0.270)$ dan diastolik $(\mathrm{P}=0.001 ; \mathrm{r}=0.372)$ yang berarah positif.

Penelitian ini menyimpulkan bahwa konseling dapat berpengaruh secara positif terhadap kepatuhan pada kelompok perlakuan dibanding kontrol dan menurunkan tekanan darah sistolik dan diastolik hingga mencapai target. Terdapat hubungan yang erat antara penurunan tekanan darah dengan skor MMAS pada pasien hipertensi.

Kata Kunci : Hipertensi, konseling, rawat jalan, kepatuhan

\section{A. PENDAHULUAN}

Depkes (2007) menganjurkan perlunya pendekatan yang lebih komprehensif dan intensif guna mencapai pengontrolan tekanan darah secara optimal. Maka untuk mencapai tujuan tersebut, diperlukan partisipasi aktif Apoteker dalam melaksanakan praktek profesinya pada setiap tempat pelayanan kesehatan. Apoteker dapat bekerja sama dengan Dokter dalam memberikan edukasi ke pasien mengenai hipertensi, memonitor respon pasien melalui farmasi komunitas, adherence terhadap terapi obat dan non-obat, mendeteksi dan mengenali seara dini reaksi efek samping, serta mencegah dan/atau memecahkan masalah yang berkaitan dengan pemberian obat.

Penelitian ini bertujuan untuk menilai pengaruh konseling Apoteker pada penanganan hipertensi dalam perbaikan kontrol tekanan darah dan kepatuhan pasien dewasa yang berobat jalan di RSUD Kraton Kabupaten Pekalongan. Kepatuhan pasien dilukur menggunakan the new 8-item self report Morisky Medication Adherence Scale (MMAS). Skala self-report ini telah dikembangkan oleh Morisky et al., (2008).

\section{B. METODE PENELITIAN}

Penelitian ini merupakan penelitian intervensional yang berupa prapascaintervensi dengan kelompok kontrol dengan randomisasi tanpa matching. Subyek penelitian adalah semua pasien hipertensi rawat jalan di poliklinik penyakit dalam RSUD Kraton Kabupaten Pekalongan periode Juli-September 2010. Kriteria inklusi adalah pasien dewasa usia 18-65 tahun, berobat di poliklinik penyakit dalam 
RSUD Kraton Kabupaten Pekalongan, mendapat obat antihipertensi, dan bersedia mengikuti penelitian. Kriteria eksklusi adalah pasien dengan buta huruf dan sedang hamil. Instrumen yang digunakan dalam penelitian ini adalah lembar penelitian yang berisi riwayat pengobatan, kuesioner kepatuhan penggunaan obat diukur dengan the new 8-item self report Morisky Modified Adherence Scale, resep, rekam medik, lembar hasil laboratorium. Pasien yang terlibat dalam penelitian ini dibagi menjadi kelompok kontrol dan kelompok perlakuan. Kelompok kontrol hanya diberikan leaflet pada awal penelitian, kelompok perlakuan mendapatkan leaflet pada awal penelitian dan konseling diberikan tiap bulan selama 3 bulan. Setelah semua data yang dibutuhkan diperoleh yaitu data rekam medik, penilaian kesehatan, kuesioner MMAS, data tekanan darah, dilakukan pengolahan data dengan metode statistik menggunakan program SPSS versi 15 .

\section{HASIL DAN PEMBAHASAN}

Pada penelitian ini diperoleh 92 subyek penelitian yang termasuk kriteria inklusi. Dari 92 subyek tersebut, subyek yang mengikuti penelitian dari awal sampai akhir sebanyak 75 subyek, terdiri dari 36 pasien kelompok kontrol dan 39 pasien hipertensi kelompok perlakuan. Pengambilan sampel dilakukan dengan metode consecutive sampling yaitu semua subyek yang datang dan memenuhi kriteria pemilihan dimasukkan dalam penelitian. Subyek yang memenuhi kriteria penelitian dibagi menjadi dua kelompok dengan cara subyek dengan urutan ganjil dimasukkan kedalam kelompok kontrol dan subyek dengan urutan genap dimasukkan kedalam kelompok perlakuan. Penelitian ini tidak dilakukan proses (penyetaraan).

Tabel 1. Karakteristik Subyek Penelitian Pasien Hipertensi di RSUD Kraton Kabupaten Pekalongan

\begin{tabular}{|c|c|c|c|c|c|}
\hline \multirow[t]{2}{*}{ Karakteristik Pasien } & \multicolumn{2}{|c|}{ Kelompok Perlakuan } & \multicolumn{2}{|c|}{ kelompok Kontrol } & \multirow{2}{*}{$\begin{array}{c}\begin{array}{c}\text { Pearson } \\
\text { ChiSquare }\end{array} \\
\mathrm{P}\end{array}$} \\
\hline & $\begin{array}{c}\begin{array}{c}\text { Jumlah } \\
(\mathrm{n}=39)\end{array} \\
\end{array}$ & $\%$ & $\begin{array}{c}\begin{array}{c}\text { Jumlah } \\
(\mathrm{n}=36)\end{array} \\
\end{array}$ & $\%$ & \\
\hline Jenis Kelamin & & & & & 0.624 \\
\hline Laki-laki & 14 & 35.9 & 11 & 30.6 & \\
\hline Perempuan & 25 & 64.1 & 25 & 69.4 & \\
\hline Usia (tahun) & & & & & 0.814 \\
\hline $40-49$ & 12 & 30.8 & 9 & 25.0 & \\
\hline $50-59$ & 20 & 51.3 & 21 & 58.3 & \\
\hline$\geq 60$ & 7 & 17.9 & 6 & 16.7 & \\
\hline Tingkat Hipertensi (mmHg) & & & & & 0.668 \\
\hline Prehipertensi & 1 & 2.6 & 1 & 2.8 & \\
\hline Hipertensi Derajat I & 18 & 46.2 & 19 & 52.8 & \\
\hline Hipertensi Derajat II & 20 & 51.3 & 16 & 44.4 & \\
\hline \multicolumn{6}{|l|}{ Risiko Kardiovaskuler } \\
\hline Merokok & & & & & 0.573 \\
\hline Ya & 8 & 20.5 & 5 & 13.9 & \\
\hline Tidak & 31 & 79.5 & 31 & 86.1 & \\
\hline Hiperlipidemia & & & & & 0.213 \\
\hline $\mathrm{Ya}$ & 24 & 61.5 & 17 & 47.2 & \\
\hline Tidak & 15 & 38.5 & 19 & 52.8 & \\
\hline DM & & & & & 0.228 \\
\hline Ya & 23 & 59.0 & 26 & 72.2 & \\
\hline Tidak & 16 & 41.0 & 10 & 27.8 & \\
\hline
\end{tabular}


Tabel 2. Terapi Anti Hipertensi yang Digunakan Pada Pasien Hipertensi di Poliklinik RSUD Pekalongan Periode Juli-Oktober 2010

\begin{tabular}{|c|c|c|c|c|c|c|c|c|}
\hline \multirow[t]{3}{*}{ Terapi Obat AntiHipertensi } & \multicolumn{4}{|c|}{$\begin{array}{c}\text { Kelompok Perlakuan } \\
(\mathrm{n}=39)\end{array}$} & \multicolumn{4}{|c|}{$\begin{array}{c}\text { Kelompok Kontrol } \\
(\mathrm{n}=36)\end{array}$} \\
\hline & \multicolumn{2}{|c|}{ Awal } & \multicolumn{2}{|c|}{ Akhir } & \multicolumn{2}{|c|}{ Awal } & \multicolumn{2}{|c|}{ Akhir } \\
\hline & $\Sigma$ & $\%$ & $\Sigma$ & $\%$ & $\Sigma$ & $\%$ & $\Sigma$ & $\%$ \\
\hline \multicolumn{9}{|l|}{ Monoterapi Obat Antihipertensi } \\
\hline Diuretik & 1 & 2.56 & 3 & 7.69 & 3 & 8.33 & 2 & 5.56 \\
\hline $\mathrm{ACEI}$ & 3 & 7.69 & 5 & 12.82 & 3 & 8.33 & 4 & 11.11 \\
\hline$\beta$-Blocker & 1 & 2.56 & 2 & 5.13 & 1 & 2.78 & 0 & 0 \\
\hline $\mathrm{CCB}$ & 5 & 12.82 & 7 & 17.95 & 3 & 8.33 & 5 & 13.89 \\
\hline ARB & 3 & 7.69 & 3 & 7.69 & 2 & 5.56 & 1 & 2.78 \\
\hline \multicolumn{9}{|l|}{ Kombinasi 2 Obat Antihipertensi } \\
\hline ACEI+Diuretik & 4 & 10.26 & 3 & 7.69 & 2 & 5.56 & 1 & 2.78 \\
\hline $\mathrm{CCB}+$ Diuretik & 6 & 15.38 & 5 & 12.82 & 5 & 13.89 & 6 & 16.67 \\
\hline $\mathrm{ACEI}+\mathrm{CCB}$ & 7 & 17.95 & 8 & 20.51 & 9 & 25 & 10 & 27.78 \\
\hline ARB+Diuretik & 1 & 2.56 & 0 & 0 & 2 & 5.56 & 0 & 0 \\
\hline \multicolumn{9}{|l|}{ Kombinasi 3 Obat Antihipertensi } \\
\hline $\mathrm{ACEI}+$ Diuretik+CCB & 5 & 12.82 & 2 & 5.13 & 3 & 8.33 & 4 & 11.11 \\
\hline $\mathrm{ACEI}+$ Diuretik+ARB & 2 & 5.13 & 1 & 2.56 & 2 & 5.56 & 3 & 8.33 \\
\hline - Alocker & 1 & 2.56 & 0 & 0 & 1 & 2.78 & 0 & 0 \\
\hline $\begin{array}{l}\text { Nilai P } \\
\text { (Uji Beda terapi antihipertensi }\end{array}$ & \multicolumn{4}{|c|}{ Pada awal penelitian } & \multicolumn{4}{|c|}{ Pada akhir penelitian } \\
\hline antara kedua kelompok) & \multicolumn{4}{|c|}{0.836} & \multicolumn{4}{|c|}{0.69} \\
\hline
\end{tabular}

\section{Keterangan:}

ACEI: Angiotensin Converting Enzyme Inhibitor

CCB: Calcium Channel Blocker

ARB: Angiotensin Reseptor Blocker

Tabel 3. Skor MMAS pada Pasien Hipertensi Kelompok Perlakuan Setelah Mendapat Konseling dan Kelompok Kontrol pada Akhir Penelitian

\begin{tabular}{|c|c|c|c|c|c|c|}
\hline \multirow{2}{*}{ Kelompok } & \multicolumn{7}{|c|}{ Skor MMAS } \\
\cline { 2 - 7 } & \multicolumn{2}{|c|}{ Kepatuhan Tinggi } & \multicolumn{2}{c|}{ Kepatuhan Sedang } & Kepatuhan Rendah \\
\cline { 2 - 7 } & $\Sigma$ & $\%$ & $\Sigma$ & $\%$ & $\Sigma$ & $\%$ \\
\hline Kontrol $(\mathrm{n}=36)$ & 1 & 2.78 & 9 & 25 & 26 & 72.22 \\
\hline Perlakuan $(\mathrm{n}=39)$ & 13 & 33.33 & 16 & 41.03 & 10 & 25.64 \\
\hline
\end{tabular}

Keterangan :

MMAS : Morishy Medication Adherence Scale

Awal penelitian dilakukan pengumpulan data klinik dan data sosiodemografi. Karakteristik data subyek penelitian data dilihat pada tabel 8 .

Pola peresepan obat anti hipertensi (OAH) pada subyek penelitian dapat dilihat pada tabel 2. Adanya pola peresepan yang sama antara kelompok kontrol dan perlakuan dapat memperkuat hasil penelitian karena tidak dipengaruhi oleh variabel tersebut.

Pola peresepan OAH ini umumnya sesuai dengan algoritma penanganan hipertensi menurut JNC VII. Pasien dengan hipertensi derajat I (140-159/90-100 mmHg) tanpa komplikasi umumnya mendapat monoterapi dari salah satu kelas OAH yang direkomendasikan yaitu diuretik, ACEInhibitor, â-blocker, ataupun calcium channel blocker. Pasien dengan derajat 2 (e"160/e"100 mmHg) tanpa komplikasi umumnya langsung diberikan kombinasi 2 kelas OAH. Perubahan peresepan yang terjadi berdasarkan pada pertimbangan 
tekanan darah saat pasien kontrol di poliklinik penyakit dalam RSUD Kraton Kabupaten Pekalongan

Penilaian kepatuhan dengan menggunakan MMAS dilakukan setelah penelitian berjalan selama 3 bulan baik pada kelompok kontrol maupun kelompok perlakuan. Hasil yang terlihat dalam tabel 3 adalah kepatuhan tinggi (skor MMAS = 8) lebih besar pada kelompok perlakuan $(33.33 \%>2.78 \%)$. Hal ini menunjukkan bahwa konseling Apoteker dapat memberikan dampak positif bagi kepatuhan pasien pada kelompok perlakuan.

Pendekatan untuk menaksir kepatuhan pengobatan bisa dengan patient self report, pill counts, pharmacy records, drug levels. Pengukuran dengan menggunakan patient self report lebih ringkas, cepat dan mudah digunakan. Namun kelemahannya adalah penilaiannya lebih bersifat subjektif (Cook et al., 2005; Garber et al., 2004).

MMAS menyediakan informasi mengenai kebiasaan yang berhubungan dengan rendahnya kepatuhan yang mungkin disebabkan oleh ketidaksengajaan (contohnya kelalaian), sengaja (tidak minum obat saat merasa bertambah parah). Identifikasi kebiasaan ini dapat memudahkan dalam memberikan intervensi sesuai dengan pokok permasalahan.

Tabel 4. Tekanan Darah Sistolik pada Awal Penelitian, Setelah 1 bulan, dan Setelah 2 bulan Tanpa Konseling pada Pasien Hipertensi Kelompok Kontrol

\begin{tabular}{|c|c|c|c|}
\hline \multirow{2}{*}{} & \multicolumn{3}{|c|}{ Kelompok Kontrol } \\
\cline { 2 - 4 } & Awal & Setelah 1 bulan & Setelah 2 bulan \\
\hline Rerata TDS(mmHg) & $152.22 \pm 12.50$ & $149.17 \pm 12.50$ & $150 \pm 9.86$ \\
\hline $\begin{array}{c}\text { Nilai P } \\
\text { (uji beda dengan TDS awal) }\end{array}$ & & $0.008^{*}$ & $0.203^{*}$ \\
\hline
\end{tabular}

Keterangan

TDS: Tekanan darah sistolik

*: menggunakan uji Wilcoxon

Tabel 5. Tekanan Darah Sistolik pada Awal Penelitian, Setelah 1 bulan, dan Setelah 2 bulan Mendapat Konseling pada Pasien Hipertensi Kelompok Perlakuan

\begin{tabular}{|c|c|c|c|}
\hline \multirow{2}{*}{} & \multicolumn{3}{|c|}{ Kelompok Perlakuan } \\
\cline { 2 - 4 } & Awal & Setelah 1 bulan & Setelah 2 bulan \\
\hline Rerata TDS(mmHg) & $152.05 \pm 11.96$ & $145.64 \pm 10.95$ & $140.77 \pm 7.39$ \\
\hline $\begin{array}{c}\text { Nilai P } \\
\text { (uji beda dengan TDS awal) }\end{array}$ & & $0.000^{*}$ & $0.000^{*}$ \\
\hline
\end{tabular}

Keterangan:

TDS: Tekanan darah sistolik

*: menggunakan uji Wilcoxon

Tabel 6. Rerata Perubahan $(\Delta)$ Tekanan Darah Sistolik pada Pasien Hipertensi Kelompok Perlakuan dan Kelompok Kontrol Setelah 1 bulan dan 2 bulan Dibandingkan dengan Awal Penelitian

\begin{tabular}{|c|c|c|}
\hline \multirow{2}{*}{ Kelompok } & \multicolumn{2}{|c|}{ Rerata Perubahan TDS $(\mathrm{mmHg})$} \\
\cline { 2 - 3 } & Setelah 1 bulan & Setelah 2 bulan \\
\hline Kontrol & $3.06 \pm 6.24$ & $2.22 \pm 10.45$ \\
\hline Perlaluran & $6.41 \pm 1.01$ & $11.28 \pm 8.33$ \\
\hline Nilai P & $0.072^{*}$ & $0.000^{*}$ \\
\hline
\end{tabular}

\section{Keterangan:}

TDS: Tekanan darah sistolik

* menggunakan uji Mann-Whitney 
Tabel 7. Tekanan Darah Diastolik pada Awal Penelitian, Setelah 1 bulan, dan Setelah 2 bulan Tanpa Konseling pada Pasien Hipertensi Kelompok Kontrol

\begin{tabular}{|c|c|c|c|}
\hline & \multicolumn{3}{|c|}{ Kelompok Kontrol } \\
\cline { 2 - 4 } & Awal & Setelah 1 bulan & Setelah 2 bulan \\
\hline Rerata TDD (mmHg) & $89.44 \pm 8.60$ & $87.78 \pm 7.22$ & $89.17 \pm 6.92$ \\
\hline $\begin{array}{c}\text { Nilai P } \\
\text { (uji beda dengan TDD awal) }\end{array}$ & & $0.109 *$ & $0.782^{*}$ \\
\hline
\end{tabular}

Keterangan :

TDD : Tekanan darah diastolik

* : menggunakan uji Wilcoxon

Tabe1 8. Tekanan Darah Diastolik pada Awal Penelitian, Setelah 1 bulan, dan Setelah 2 bulan Mendapat Konseling pada Pasien Hipertensi Kelompok Perlakuan

\begin{tabular}{|c|c|c|c|}
\hline \multirow{2}{*}{} & \multicolumn{3}{|c|}{ Kelompok Perlakuan } \\
\cline { 2 - 4 } & Awal & Setelah 1 bulan & Setelah 2 bulan \\
\hline Rerata TDD (mmHg) & $92.05 \pm 7.32$ & $87.95 \pm 6.56$ & $84.87 \pm 5.56$ \\
\hline Nilai P & & $0.001^{*}$ & $0.000^{*}$ \\
\hline (uji beda dengan TDD awal) & & & \\
\hline
\end{tabular}

Keterangan:

TDD: Tekanan darah diastolik

*: menggunakan uji Wilcoxon

Tabel 9. Rerata Penurunan $(\Delta)$ Tekanan Darah Diastolik pada Pasien Hipertensi Kelompok Perlakuan dan Kelompok Kontrol Setelah 1 bulan dan 2 bulan Dibandingkan dengan Awal Penelitian

\begin{tabular}{|c|c|c|}
\hline \multirow{2}{*}{ Kelompok } & \multicolumn{2}{|c|}{ Rerata Penurunan TDD (mmHg) } \\
\cline { 2 - 3 } & Setelah 1 bulan & Setelah 2 bulan \\
\hline Kontrol & $1.67 \pm 6.09$ & $0.28 \pm 6.09$ \\
\hline Perlakuan & $4.10 \pm 6.77$ & $7.18 \pm 6.86$ \\
\hline Nilai $\mathbb{P}$ & $0.139^{*}$ & $0.000^{*}$ \\
\hline
\end{tabular}

Keterangan:

TDD: Tekanan darah diastolik

*: menggunakan uji Mann-Whitney

Tabel 10. Hasil uji Beda Pencapaian Target Tekanan Darah menurut JNC VII pada Pasien Hipertensi Kelompok Perlakuan dan Kelompok Kontrol

\begin{tabular}{|c|c|c|c|c|c|}
\hline \multicolumn{6}{|c|}{$\begin{array}{l}\text { Pencapaian Target Tekanan Darah pada Akhir Penelitian. } \\
\text { (Hipertensi }<140 / 90 \mathrm{mmHg} \text {, Hipertensi+DM }<130 / 80 \mathrm{mmHg} \text { ) }\end{array}$} \\
\hline \multicolumn{2}{|c|}{$\begin{array}{l}\text { Kelompok Kontrol } \\
(\mathrm{n}=36)\end{array}$} & \multicolumn{2}{|c|}{$\begin{array}{c}\text { Kelompok Perlakuan } \\
(\mathrm{n}=39)\end{array}$} & \multirow{2}{*}{ Nilai $P$} & \multirow{2}{*}{ Keterangan } \\
\hline Jumlah & $\%$ & Jumlah & $\%$ & & \\
\hline 8 & 22.2 & 26 & 66.7 & 0.000 & $\mathrm{U}_{\mathrm{ji}}$ Mann-Whitney \\
\hline
\end{tabular}

Tabel 18. Hubungan Perubahan Tekanan Darah Setelah 2 Bulan dengan Skor MMAS Pasien Hipertensi di Poliklinik RSUD Kraton Kabupaten Pekalongan

\begin{tabular}{|c|c|c|c|}
\hline \multirow{2}{*}{ Tekanan Darah } & \multicolumn{2}{|c|}{ Skor MMAS } & \multirow{2}{*}{ Kesimpulan } \\
\cline { 2 - 3 } & Nilai $\mathrm{P}$ & Nilai $\mathbf{~}$ & \\
\hline $\begin{array}{c}\text { Perubahan sistolik } \\
\text { setelah 2 bulan }\end{array}$ & 0.019 & 0.270 & $\begin{array}{c}\text { terdapat korelasi yang bermakna,kekuatan } \\
\text { korelasi lemah, arah korelasi positif }\end{array}$ \\
\hline $\begin{array}{c}\text { Perubahan diastolik } \\
\text { setelah 2 bulan }\end{array}$ & 0.001 & 0.372 & $\begin{array}{c}\text { terdapat korelasi yang bermakna,kekuatan } \\
\text { korelasi lemah, arah korelasi positif }\end{array}$ \\
\hline
\end{tabular}


Penilaian terhadap tekanan darah baik pada kelompok kontrol maupun kelompok perlakuan dilakukan tiga kali selama penelitian, yakni pada awal penelitian, satu bulan, dan dua bulan setelah penelitian berjalan.

Jumlah pencapaian target tekanan darah pada kedua kelompok penelitian pada akhir penelitian dapat dilihat pada tabel 10 . Untuk mengetahui adanya hubungan hasil terapi dengan kepatuhan, maka dilakukan uji korelasi. Hasil terapi yang dikorelasikan dengan kepatuhan adalah penurunan tekanan darah baik pada sistolik dan diastolik dengan skor MMAS. Uji korelasi secara statistik yang digunakan adalah Uji Pearson. Dipilih uji ini karena variabel yang diujikan berupa variabel numerik dengan numerik

Hasil uji ini menunjukkan ada hubungan yang bermakna antara penurunan tekanan darah sistolik dan diastolik dengan skor MMAS pasien hipertensi yang menjadi subyek penelitian di poliklinik RSUD Kraton Kabupaten Pekalongan. Hal tersebut sesuai dengan kondisi yang diharapkan, yaitu adanya hubungan yang signifikan antara penurunan hasil terapi dengan skor MMAS, walaupun koefisien korelasi pada keduanya menunjukkan hubungan yang lemah. Hal ini bisa dikarenakan konseling bukan faktor yang dominan dalam menurunkan tekanan darah. Banyak faktor yang memperngaruhi tekanan darah, antara lain ketepatan pemilihan obat, kepatuhan minum obat, dan perubahan gaya hidup yang dilakukan oleh pasien. Arah korelasi keduanya adalah positif, yang berarti semakin besar perbedaan tekanan darah seseorang maka akan semakin tinggi pula skor MMASnya.

\section{A. KESIMPULAN}

Penelitian ini menyimpulkan bahwa konseling Apoteker dapat berpengaruh secara positif terhadap kepatuhan pada kelompok perlakuan dibandingkan dengan kelompok kontrol pada pasien hipertensi, juga dapat menurunkan tekanan darah sistolik dan diastolik yang signifikan pada pasien hipertensi hingga mencapai target. Terdapat hubungan yang signifikan antara kepatuhan dengan hasil terapi pada pasien rawat jalan poliklinik RSUD Kraton Kabupaten Pekalongan.

\section{DAFTAR PUSTAKA}

Case Management Society of America, 2006, Case Management Adherence Guidelines, version 2.0, Case Management Society of America

Chobanian, A.V., Bakris, J.L., Black, H.R., Cushman, W.C., green, L.A., Izzo Jr, J.L., jones, D.W., et al., 2003, The seventh report of The Joint national Committee on prevention, detection, evaluation and treatment of high blood pressure, US Department of Health and human Services

Cook, C.L., Wade, W.E., Martin B.C., Perri M., 2005, Concordance Among Three Self-Reported Measures of Medication Adherence and Pharmacy Refill Records, J Am Pharm Assoc., 45(2):151-9

Dep. Kes. RI, 2007, Pharmaceutical Care untuk Penyakit Hipertensi, Pedoman Konseling Pelayanan Kefarmasian di Sarana Kesehatan. Direktorat Jenderal Bina Farmasi, Jakarta

Garber, M.C., Nau, D.P., Erickson, S.R., Aikens, J.E., Lawrence, J.B., 2004, The Concordance of Self-Report with Other Measures of Medication Adherence: A Summary of The Literature, Med Care, 42(7): 649-52 
Morisky, D.E.,Ang, A., Krousel-Wood, M.A., Ward, H., 2008, Predictive Validity of A Medication Adherence Measure in an Outpatient Setting, $J$. Clin. Hyperiens, 10:348-54

Palaian, S., Mukhyaprana, P., Ravi, S., 2006, Patient Counseling by Pharmacist-A Focus on Chronic Illness, Pak. J. Pharm. Sci., 19 (1) : 62-65 